\title{
PERBANDINGAN PEMEROLEHAN \\ BAHASA INGGRIS SEBAGAI BAHASA ASING \\ ANTARA PEMBELAJAR PEREMPUAN DAN PEMBELAJAR LAKI-LAKI \\ MAHASISWA PROGRAM STUDI SASTRA INGGRIS \\ UNIVERSITAS DEHASEN BENGKULU
}

\author{
Silvia Erlin Aditya. SM; Djatmika; Riyadi Santosa \\ Magister Linguistik Deskriptif Pascasarjana Universitas Sebelas Maret Surakarta \\ sembiring_s@ymail.com
}

\begin{abstract}
Silvia Erlin Aditya. SM. S111308009. Investigating Foreign Language Acquisition between Female and Male Learners in English Department Study Program, Universitas Dehasen Bengkulu. Supervisor: (1) Prof. Dr. Djatmika, M.A (2) Prof. Drs. Riyadi Santosa, M.Ed., Ph.D. Article. Post Graduate Program in Linguistics, Majoring Descriptive Linguistics. Sebelas Maret University. Surakarta.
\end{abstract}

The article talks about the process of acquiring English as a foreign language between male and female learners in English department, UNIVED. Data in the form of document were collected through students writing on descriptive and narrative texts from 28th September 2015 to 31th October 2015. The data were analysed through performance analysis in order to find out learners' acquisition in composing descriptive and narrative text in English, to observe the process of acquiring English grammatical, to investigate learners' language learning level through their acquisition on English word formation and to compare learners' acquisition on foreign language based on their gender differences.

The findings show that : (1) Description text is a genre that have been well mastered by learners of English in UNIVED; (2) Learners have a low ability in acquiring English grammar with misformation and misapplied error category; (3) Learners are found in Elementary level based on their acquisition on word format; (4) Male learners exceed female learners in acquiring English. In general, the study shows that the acquisition of English as a Foreign Language of male and female learners in UNIVED is in low category.

Keywords: descriptive, narrative, grammar, word format, foreign language acquisition.

\section{PENDAHULUAN}

Fenomena yang terjadi di masyarakat sekarang ini, yaitu sifat yang mengedepankan kualitas keberhasilan berstandar materi. Dengan demikian proses pembelajaran dan pembentukan mental generasi orientasinya ke arah kemapanan secara 
materi. Seluruh proses yang akan mendukung tujuan tersebut dibuat dan diformat untuk mengikuti perkembangan zaman. Akibatnya, orang berlomba-lomba untuk menguasai keahlian yang dianggap dapat menyelamatkan dalam persaingan global. Salah satunya menguasai bahasa-bahasa yang secara ekonomi lebih menguntungkan (Bahasa Indonesia dan Bahasa Inggris). Bahasa Indonesia dan bahasa Asing/ Inggris dianggap bahasa yang mempunyai tingkatan yang lebih tinggi. (Marmanto, 2012). Berlatar belakang alasan tersebut kemudian pemerintah memasukkan Bahasa asing seperti bahasa Inggris ke dalam kurikulum pembelajaran di sekolah-sekolah.

Menurut UU Nomor 20 Tahun 2003 tentang sistem Pendidikan Nasional (Sisdiknas) Pasal 6 ayat 1 yang berbunyi "Setiap warga Negara yang berusia tujuh sampai dengan lima belas tahun wajib mengikuti pendidikan dasar". Berdasarkan UU Sisdiknas ini dapat kita simpulkan bahwa anak-anak yang belajar di sekolah-sekolah sudah melewati masa kritis mereka saat belajar bahasa asing/Inggris. Dengan demikian proses pembelajaran bahasa pada usia sekolah disebut juga dengan pemerolehan bahasa kedua/Asing.

Usia dan pemerolehan bahasa merupakan salah satu isu kunci dalam penelitian SLA (Second Language Acquisition). Pemerolehan bahasa kedua/asing merupakan studi yang sangat menarik. Ruang lingkup penelitiannyapun luas mencakup aspek linguistik, sosial dan pengajaran. Penelitian SLA yang berkonsentrasi penuh pada pemerolehan aspek linguistik secara terperinci mengulas tentang pemerolehan aspek morfologi, sintaksis, fonologi dan gramatika. Keempat hal tersebut merupakan aspek linguistik yang sangat penting dalam proses pemerolehan sebuah bahasa.

Selain itu menurut Chaer (2009) proses pemerolehan bahasa kedua/asing hanya dapat dikuasai dengan proses belajar dengan cara sengaja dan sadar. Fundamental dalam 
memahami SLA adalah memahami dan mengerti apa saja aspek yang wajib dikuasai untuk dapat dikategorikan bahwa seorang pembelajar bahasa dikatakan berhasil memperoleh bahasa yang menjadi targetnya. Menurut Gass \& Selinker (2008 )seorang pembelajar bahasa dinyatakan memperoleh bahasa keduanya apabila menguasai beberapa aspek bahasa. Aspek bahasa tersebut adalah aspek fonologi, sintak/gramatikal, morfologi/bentuk kata, semantik dan pragmatik.

Dalam artikel ini penulis akan melakukan penelitian mengenai SLA di lingkungan formal. Tujuan penelitian ini adalah untuk mengetahui keterampilan menulis teks deskriptif dan naratif dalam bahasa Inggris dilihat dari struktur teks yang digunakan dalam mengarang, untuk mengetahui pemerolehan gramatikal bahasa Inggris sebagai bahasa asing, untuk mengetahui pemerolehan format kata bahasa Inggris untuk mendeteksi level atau tingkatan pemerolehan bahasa Inggris dan menemukan siapakah yang lebih baik pemerolehan bahasa Inggrisnya antara pembelajar perempuan dengan pembelajar laki-laki para pembelajar dewasa di komunitas pendidikan formal yaitu mahasiswa sastra Inggris Universitas Dehasen Bengkulu.

\section{METODOLOGI PENELITIAN}

Penelitian ini merupakan penelitian etnografi berbentuk deskriptif kualitatif dan menggunakan pendekatan performance analysis (PA). Lokasi pada penelitian ini adalah demografis, Tempat dari penelitian ini adalah Program Studi Sastra Inggris Universitas Dehasen Bengkulu. Partisipannya adalah mahasiswa dan mahasiswi semester 5 dan 7. Kejadian yang diteliti adalah dua genre teks yaitu teks deskriptif dan teks naratif. Sumber data adalah informan dan dokumen. Data dalam penelitian ini adalah satuan lingual yang mengandung struktur teks, aspek gramatikal (copula, auxiliaries, third person singular, -ing, regular \& irregular past, article, plural, possessive) dan format 
kosakata (compound word, blends, dan clipped form) yang ditulis oleh para pembelajar bahasa tersebut. Penelitian ini menggunakan tehnik analisis dokumen.

\section{HASIL PENELITIAN DAN PEMBAHASAN}

Ada 30 orang pembelajar dalam penelitian ini, 15 orang pembelajar perempuan dan 15 orang pembelajar laki-laki. Ketigapuluh pembelajar tersebut kemudian diwajibkan menulis dua macam teks yaitu teks naratif dan teks deskriptif. Pembelajar perempuan rata-rata membuat 46 kalimat dan 95 klausa. Kalimat terbanyak dibuat oleh pembelajar F8 dimana membuat 71 kalimat dalam kedua karangannya dan kalimat yang paling sedikit dibuat oleh pembelajar F12. Total keseluruhan kalimat yang dibuat oleh pembelajar perempuan adalah 693 kalimat, 1.306 klausa dan 11. 521 kata. Sementara itu, kelompok pembelajar laki laki membuat 448 kalimat, 909 klausa dan 6.542. Kalimat terbanyak dibuat oleh pembelajar M1 dengan 51 kalimat, sedangkan pembelajar yang paling sedikit membuat kalimat adalah M4 dengan 11 kalimat.

Khusus untuk menjawab pertanyaan penelitian yang ingin membandingkan kemampuan menulis cerita antara pembelajar perempuan dengan pembelajar laki-laki, maka data yang berupa teks deskripsi dan teks naratif dianalis struktur teksnya. Pada teks deskripsi rata-rata pembelajar bahasa sudah sangat baik, hal tersebut dapat dilihat dari tabel rekapitulasi di bawah ini. 
Tabel 1 : Rekapitulasi Analisis Struktur Teks Deskripsi

\begin{tabular}{|c|c|c|c|c|c|c|c|}
\hline \multicolumn{3}{|c|}{ Pembelajar Perempuan } & \multirow{2}{*}{$\%$} & \multicolumn{3}{|c|}{ Pembelajar Laki-laki } & \multirow{2}{*}{$\%$} \\
\hline & Identification & Description & & & Identification & Description & \\
\hline F1 & $\mathbf{V}$ & $\mathbf{V}$ & $100 \%$ & M1 & $\mathbf{V}$ & $\mathbf{V}$ & $100 \%$ \\
\hline F2 & $\mathrm{X}$ & $\mathrm{V}$ & $50 \%$ & M2 & $\mathbf{V}$ & V & $100 \%$ \\
\hline F3 & $\mathbf{V}$ & $\mathbf{V}$ & $100 \%$ & M3 & $\mathbf{V}$ & $\mathbf{V}$ & $100 \%$ \\
\hline F4 & $\mathbf{V}$ & $\mathbf{V}$ & $100 \%$ & M4 & $\mathbf{x}$ & $\mathbf{X}$ & $0 \%$ \\
\hline F5 & $\mathbf{V}$ & $\mathbf{V}$ & $100 \%$ & M5 & $\mathbf{V}$ & $\mathbf{V}$ & $100 \%$ \\
\hline F6 & $\mathbf{V}$ & $\mathbf{V}$ & $100 \%$ & M6 & $\mathbf{V}$ & V & $100 \%$ \\
\hline F7 & $\mathbf{V}$ & $\mathbf{V}$ & $100 \%$ & M7 & $\mathbf{V}$ & $\mathbf{V}$ & $100 \%$ \\
\hline F8 & $\mathbf{V}$ & $\mathbf{V}$ & $100 \%$ & M8 & $\mathbf{v}$ & $\mathbf{V}$ & $100 \%$ \\
\hline F9 & $\mathbf{X}$ & V & $50 \%$ & M9 & $\mathbf{V}$ & V & $100 \%$ \\
\hline F10 & $\mathbf{V}$ & $\mathbf{V}$ & $100 \%$ & M10 & $\mathbf{v}$ & $\mathbf{V}$ & $100 \%$ \\
\hline F11 & $\mathbf{V}$ & $\mathbf{V}$ & $100 \%$ & M11 & $\mathbf{V}$ & $\mathbf{V}$ & $100 \%$ \\
\hline F12 & $\mathbf{V}$ & $\mathbf{V}$ & $100 \%$ & M12 & $\mathbf{V}$ & V & $100 \%$ \\
\hline F13 & $\mathbf{V}$ & $\mathbf{V}$ & $100 \%$ & M13 & $\mathbf{v}$ & $\mathbf{V}$ & $100 \%$ \\
\hline F14 & $\mathbf{V}$ & V & $100 \%$ & M14 & $\mathbf{V}$ & V & $100 \%$ \\
\hline \multirow[t]{2}{*}{ F15 } & $\mathbf{V}$ & $\mathbf{V}$ & $100 \%$ & M15 & $\mathbf{V}$ & $\mathbf{V}$ & $100 \%$ \\
\hline & & & $93 \%$ & & & & $93 \%$ \\
\hline
\end{tabular}

Sedangkan hasil analisis struktur teks naratif dijelaskan dalam tabel rekapitulasi 4.2 sebagai berikut.

Tabel 2 : Rekapitulasi Analisis Struktur Teks Naratif

\begin{tabular}{|c|c|c|c|c|c|c|c|c|c|}
\hline \multicolumn{4}{|c|}{ Penutur Perempuan } & \multirow[b]{2}{*}{$\%$} & \multicolumn{4}{|c|}{ Penutur Laki-laki } & \multirow[b]{2}{*}{$\%$} \\
\hline & Orientation & Complication & Resolution & & & Orientation & Complication & Resolution & \\
\hline F1 & $\mathbf{v}$ & $\mathbf{v}$ & $\mathbf{v}$ & $100 \%$ & M1 & $\mathbf{v}$ & $\mathbf{v}$ & $\mathbf{v}$ & $100 \%$ \\
\hline F2 & $\mathbf{v}$ & $\mathbf{v}$ & $\mathbf{v}$ & $100 \%$ & M2 & $\mathbf{v}$ & $\mathbf{v}$ & $\mathbf{v}$ & $100 \%$ \\
\hline F3 & $\mathbf{V}$ & $\mathbf{v}$ & $\mathbf{v}$ & $100 \%$ & M3 & $\mathbf{v}$ & $\mathrm{v}$ & $\mathbf{v}$ & $100 \%$ \\
\hline F4 & $\mathbf{v}$ & $\mathbf{v}$ & $\mathbf{v}$ & $100 \%$ & M4 & $\mathbf{v}$ & $\mathbf{v}$ & $\mathbf{v}$ & $100 \%$ \\
\hline F5 & $\mathbf{v}$ & $\mathbf{v}$ & $\mathbf{v}$ & $100 \%$ & M5 & $\mathbf{v}$ & $\mathbf{v}$ & $\mathrm{x}$ & $67 \%$ \\
\hline F6 & $\mathbf{v}$ & $\mathbf{v}$ & $\mathbf{v}$ & $100 \%$ & M6 & $\mathbf{v}$ & $\mathbf{v}$ & $\mathbf{v}$ & $100 \%$ \\
\hline F7 & $\mathrm{x}$ & $\mathrm{x}$ & $\mathrm{x}$ & $0 \%$ & M7 & $\mathbf{v}$ & $\mathbf{v}$ & $\mathbf{v}$ & $100 \%$ \\
\hline F8 & $\mathbf{v}$ & $\mathrm{x}$ & $\mathbf{x}$ & $33 \%$ & M8 & $\mathbf{v}$ & $\mathbf{x}$ & $\mathrm{x}$ & $33 \%$ \\
\hline F9 & $\mathbf{v}$ & $\mathbf{v}$ & $\mathbf{v}$ & $100 \%$ & M9 & $\mathbf{v}$ & $\mathrm{x}$ & $\mathbf{v}$ & $67 \%$ \\
\hline F10 & $\mathbf{v}$ & $\mathbf{v}$ & $\mathbf{v}$ & $100 \%$ & M10 & $\mathbf{v}$ & $\mathbf{v}$ & $\mathbf{v}$ & $100 \%$ \\
\hline F11 & $\mathbf{x}$ & $\mathrm{X}$ & $\mathbf{x}$ & $0 \%$ & M11 & $\mathbf{v}$ & $\mathbf{v}$ & $\mathbf{V}$ & $100 \%$ \\
\hline F12 & $\mathbf{V}$ & $\mathbf{V}$ & $\mathbf{v}$ & $100 \%$ & M12 & $\mathbf{v}$ & $\mathbf{v}$ & $\mathbf{V}$ & $100 \%$ \\
\hline F13 & $\mathbf{V}$ & $\mathbf{v}$ & $\mathbf{v}$ & $100 \%$ & M13 & $\mathbf{v}$ & $\mathbf{v}$ & $\mathbf{V}$ & $100 \%$ \\
\hline F14 & $\mathbf{V}$ & $\mathbf{v}$ & $\mathbf{V}$ & $100 \%$ & M14 & $\mathbf{v}$ & $\mathbf{v}$ & $\mathbf{V}$ & $100 \%$ \\
\hline \multirow[t]{2}{*}{ F15 } & $\mathbf{v}$ & $\mathbf{v}$ & $\mathbf{v}$ & $100 \%$ & M15 & $\mathbf{v}$ & $\mathbf{v}$ & $\mathbf{v}$ & $100 \%$ \\
\hline & & & & $82 \%$ & & & & & $91 \%$ \\
\hline
\end{tabular}

Pada aspek pemerolehan gramatika dari kesembilan aspek gramatikal yang dianalisis aspek plural dan possessive merupakan aspek gramatika yang paling baik penguasaannya oleh kedua kelompok pembelajar bahasa karena pemerolehannya sudah mencapai $91 \%$. Grafik di bawah ini akan memetakan dengan detil pemerolehan correct grammar kedua kelompok pembelajar bahasa. 




Grafik 1 : Hasil analisis correct grammar

Sementara itu, hasil analisis error grammar menunjukkan bahwa error grammar yang paling banyak dilakukan adalah pada aspek copula, -ing, regular verb, irregular dan plural. Grafik di bawah ini menjelaskannya lebih detil.

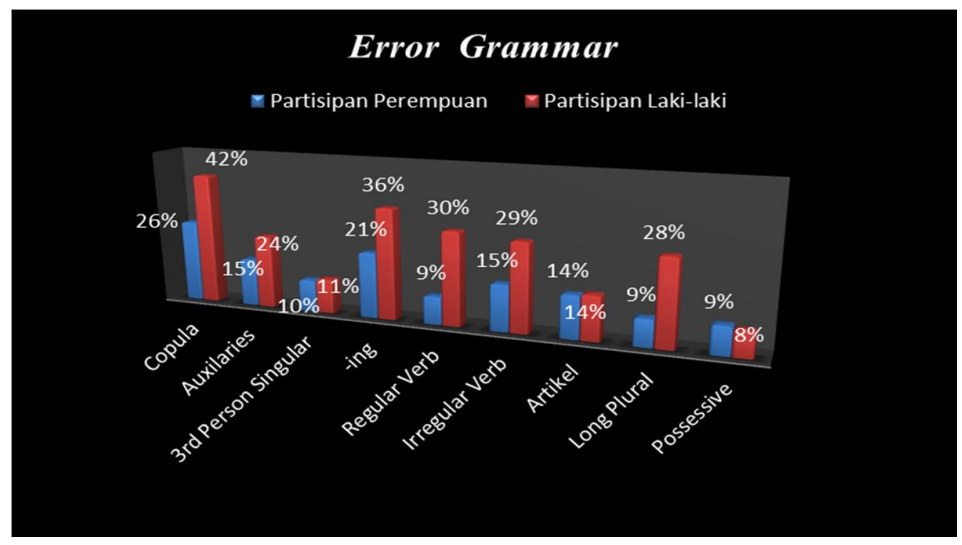

Grafik 2 : Hasil analisis error grammar.

Kesalahan atau error dalam menggunakan aspek gramatika ini penulis golongkan menjadi lima tipe. Yaitu Addition (Kesalahan karena penambahan), Ommission (kesalahan atau error sebab penghilangan), misformation (Error yang disebabkan kesalahan dalam format bahasa), Misordering (Error dikarenakan salah susunan atau salah urutan), dan yang terakhir Misapplied (digolongkan sebagai error karena penggunaannya tidak sesuai dengan bentuk tenses yang diharapkan). Berikut tabel rekapitulasi error grammar berdasarkan kategori error yang ditemukan. 


\begin{tabular}{|l|r|r|r|r|r|r|r|}
\hline FEMALE \\
\hline NO & JENIS ERROR & ADDITION & OMISSION & MISAPPLIED & IISFORMATION & MISORDERING & TOTAL \\
\hline 1 & COPULA & 32 & 25 & 46 & - & - & 103 \\
\hline 2 & AUXILARIES & 1 & 1 & 18 & - & 2 & $\mathbf{2 2}$ \\
\hline 3 & TPS & 4 & 5 & 13 & - & - & $\mathbf{2 2}$ \\
\hline 4 & -ING & 2 & 9 & - & - & - & 11 \\
\hline 5 & REGULAR VERB & - & - & 25 & - & - & $\mathbf{2 5}$ \\
\hline 6 & IRREGULAR VERB & - & - & 42 & - & - & $\mathbf{4 2}$ \\
\hline 7 & ARTICLE & 4 & 28 & 3 & - & 1 & $\mathbf{3 6}$ \\
\hline 8 & PLURAL & 6 & 3 & - & - & - & $\mathbf{9}$ \\
\hline 9 & POSSESIVE & 1 & 5 & 10 & - & - & $\mathbf{1 6}$ \\
\hline & TOTAL & $\mathbf{5 0}$ & $\mathbf{7 6}$ & 157 & $\mathbf{1 7 3}$ & 3 & $\mathbf{4 5 9}$ \\
\hline
\end{tabular}

Tabel 3 : Rekapitulasi Kategori error grammar pembelajar perempuan

\begin{tabular}{|c|c|c|c|c|c|c|}
\hline \multicolumn{7}{|l|}{ MALE } \\
\hline NO JENIS ERR0R & ADDITION & OMISSION & MISAPPLIED & MISF0RMATION & MISORDERING & TOTAL \\
\hline 1 COPULA & 16 & 35 & 51 & 7 & 1 & 110 \\
\hline \begin{tabular}{l|l}
2 & AUXILARIES \\
\end{tabular} & 3 & 1 & 25 & - & 2 & 31 \\
\hline \begin{tabular}{l|l}
3 & TPS \\
\end{tabular} & - & - & 18 & - & - & 18 \\
\hline 4 -ING & 10 & 12 & - & 2 & - & 24 \\
\hline 5 REGULAR VERB & 1 & - & 68 & 1 & - & 70 \\
\hline \begin{tabular}{l|l}
6 & IRREGULAR VERB \\
\end{tabular} & 1 & - & 78 & 1 & - & 80 \\
\hline 7 ARTICLE & 4 & 16 & 3 & - & - & 23 \\
\hline \begin{tabular}{|l|l|}
8 & PLURAL \\
\end{tabular} & 3 & 17 & - & - & - & 20 \\
\hline 9 POSSESIVE & - & 7 & 4 & - & 2 & 13 \\
\hline TOTAL & 38 & 88 & 247 & 11 & 5 & 389 \\
\hline
\end{tabular}

Tabel 4 : Rekapitulasi Kategori error grammar pembelajar laki-laki

Dari kedua tabel di atas menunjukkan bahwa misformation adalah kategori error

yang paling dominan dilakukan oleh pembelajar perempuan sedangkan kategori error

pada pembelajar laki-laki yang paling dominan ditemukan adalah misapplied.

Pada aspek pemerolehan format kata hasil analisisnya dapat dilihat dari kedua grafik di bawah ini :

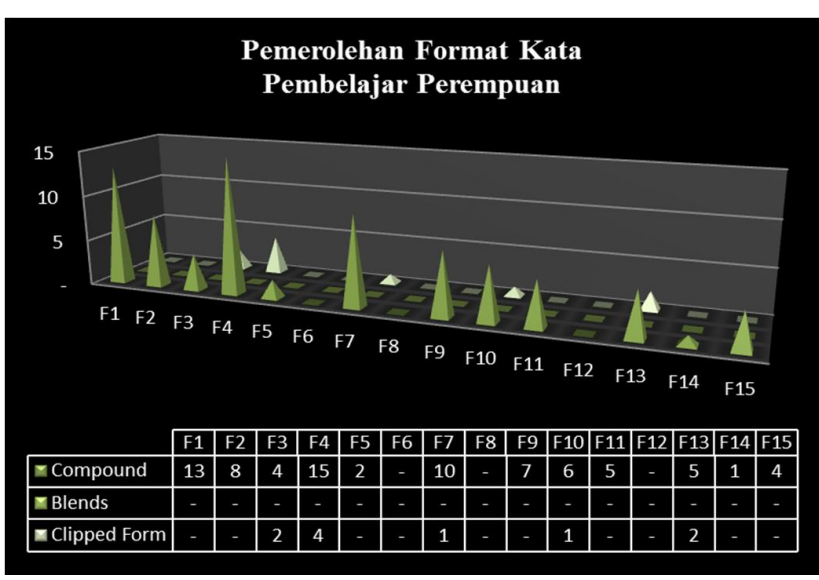

Grafik 3 : Pemerolehan Format Kata Pembelajar Perempuan

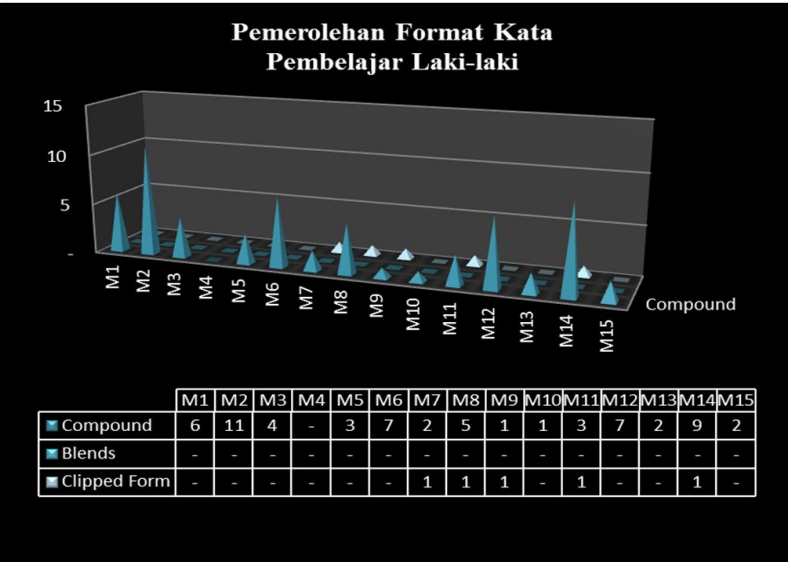

Grafik 4 : Pemerolehan Format Kata Pembelajar Laki-laki 
Dari kedua grafik pemerolehan kosakata di atas terlihat bahwa pemerolehan format kata compound word atau kata majemuk yang lebih besar pemerolehannya, yang kemudian diikuti clipped form. Sedangkan blends atau peleburan tidak ditemukan dalam penelitian ini. 


\section{PEMBAHASAN}

Hubungan semua variabel yang telah diteliti dapat dilihat pada tabel komponensial berikut ini:

\begin{tabular}{|c|c|c|c|c|}
\hline \multirow{21}{*}{ 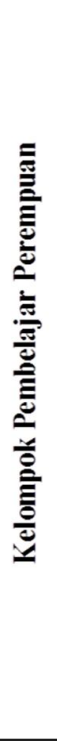 } & Genre & Aspek Analisis & Jumlah & $\%$ Tase \\
\hline & \multirow[t]{10}{*}{ Deskriptif } & Struktur Teks & & $93.00 \%$ \\
\hline & & Pemerolehan Gramatikal & & \\
\hline & & - Correct Grammar & 350 & $69.17 \%$ \\
\hline & & - Error Grammar & 156 & $30.83 \%$ \\
\hline & & - Misformation & 81 & $51.92 \%$ \\
\hline & & - Ommission & 40 & $25.64 \%$ \\
\hline & & - Misapplied & 25 & $16.03 \%$ \\
\hline & & - Addition & 8 & $5.13 \%$ \\
\hline & & - Misordering & 2 & $1.28 \%$ \\
\hline & & Pemerolehan Format Kata & 53 & $0.99 \%$ \\
\hline & \multirow[t]{10}{*}{ Naratif } & Struktur Teks & & $82.00 \%$ \\
\hline & & Pemerolehan Gramatikal & & \\
\hline & & - Correct Grammar & 511 & $63.88 \%$ \\
\hline & & - Error Grammar & 303 & $37.88 \%$ \\
\hline & & - Misapplied & 132 & $43.56 \%$ \\
\hline & & - Misformation & 92 & $30.36 \%$ \\
\hline & & - Addition & 42 & $13.86 \%$ \\
\hline & & - Ommission & 36 & $11.88 \%$ \\
\hline & & - Misordering & 1 & $0.33 \%$ \\
\hline & & Pemerolehan Format Kata & 37 & $0.60 \%$ \\
\hline \multirow{20}{*}{ 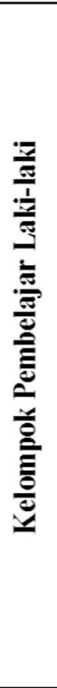 } & \multirow[t]{10}{*}{ Deskriptif } & Struktur Teks & & $93.00 \%$ \\
\hline & & Pemerolehan Gramatikal & & \\
\hline & & - Correct Grammar & 239 & $73.99 \%$ \\
\hline & & - Error Grammar & 84 & $26.01 \%$ \\
\hline & & - Ommission & 41 & $48.81 \%$ \\
\hline & & - Misapplied & 21 & $25.00 \%$ \\
\hline & & - Addition & 15 & $17.86 \%$ \\
\hline & & - Misformation & 5 & $5.95 \%$ \\
\hline & & - Misordering & 2 & $2.38 \%$ \\
\hline & & Pemerolehan Format Kata & 20 & $0.69 \%$ \\
\hline & \multirow[t]{10}{*}{ Naratif } & Struktur Teks & & $87.00 \%$ \\
\hline & & Pemerolehan Gramatikal & & \\
\hline & & - Correct Grammar & 306 & $52.22 \%$ \\
\hline & & - Error Grammar & 280 & $47.78 \%$ \\
\hline & & - Misapplied & 226 & $74.10 \%$ \\
\hline & & -Ommission & 47 & $15.41 \%$ \\
\hline & & - Addition & 23 & $7.54 \%$ \\
\hline & & - Misformation & 6 & $1.97 \%$ \\
\hline & & - Misordering & 3 & $0.98 \%$ \\
\hline & & Pemerolehan Format Kata & 68 & $1.87 \%$ \\
\hline
\end{tabular}

Tabel 5 : Analisis komponensial

Tabel 5 di atas menunjukkan bahwa kemampuan menulis teks deskripsi pada kedua kelompok pembelajar bahasa sudah sangat baik. Dimana persentasenya akurasi penulisan berdasarkan struktur teksnya mencapai 93\%. Kedua kelompok pembelajar bahasa mampu mengidentifikasi benda yang dideskripsikan. Secara spesifik mereka 
berhasil mengambarkan atau memperkenalkan benda yang menjadi impian atau harapan mereka untuk dapat dimiliki pada suatu hari nanti. Sementara itu, pada bagian deskripsi yang berisi tentang penjelasan/penggambaran tentang karakteristik dari benda yang diidentifikasi sebelumnya, kedua kelompok pembelajar tersebut dengan baik menyebutkan gambaran, karakter, atau apapun yang berhubungan dengan deskripsi benda yang dimaksud. Hal ini sesuai dengan apa yang dikemukakan oleh Djatmika (2015:15) bahwa teks deskripsi adalah teks yang menjelaskan tentang seperti apakah orang atau suatu benda dideskripsikan, baik bentuknya, sifat-sifatnya, jumlahnya dan lain-lain yang tujuannya (purpose) untuk menjelaskan, menggambarkan atau mengungkapkan seseorang atau suatu benda, baik abstrak maupun konkret.

Pada genre teks deskripsi pemerolehan gramatikal kelompok pembelajar perempuan dapat dikatakan belum cukup baik. Dimana persentase correctness penggunaan 9 aspek gramatikal hanya $69.17 \%$ sedangkan error grammar $30.83 \%$. Error grammar yang paling banyak dilakukan oleh kelompok pembelajar perempuan adalah kategori misformation, dimana persentase error grammar pada kategori ini mencapai 51.92\%. Misformation adalah kesalahan gramatikal yang terjadi apabila partisipan membentuk suatu frasa atau kalimat yang tidak sesuai kaidah bahasa. Akibatnya konstruksi frasa atau kalimat menjadi salah atau penyimpangan kaidah bahasa. Klausa yang dikategorikan misformation dikarenakan tidak membentuk struktur kalimat sesuai dengan pola dasar kaidah bahasa Inggris seperti tidak membentuk pola S-V (Subject-Verb), S-V-O (Subject-Verb-Object), S-V-Adj (Subject-Verb-Adjective), S-V-Adv (Subject-Verb-Adverb) dan S-V-N (Subject-Verb-Noun). Selanjutnya klausaklausa tersebut mencampurkan kosakata bahasa Indonesia kedalamnya sehingga makna yang ingin disampaikan dari klausa yang dibuat tidak dapat dipahami dengan baik. 
Ujaran-ujaran dalam klausa tidak gramatika pada taraf kalimat dan tidak bisa ditafsirkan dalam konteks komunikasi. Kategori error grammar selanjutnya pada genre teks deskripsi kelompok pembelajar perempuan adalah omission, misapplied, addition dan misordering.

Pada kelompok pembelajar laki-laki correct grammar dalam menulis deskripsi teks sudah cukup baik persentasenya $73.99 \%$. Sedangkan persentase error grammar kelompok ini $26.01 \%$. Error grammar pada genre teks deskripsi terbanyak dilakukan kelompok pembelajar laki-laki pada kategori ommission yaitu 48.81\%. Ommission adalah Error grammar yang dikarenakan partisipan menghilangkan satu atau lebih aspek gramatika yang diperlukan dalam klausa atau kalimat yang mereka buat. Kemudian diikuti dengan misapplied, addition, misformation, dan misordering.

Pada aspek pemerolehan format kata kelompok pembelajar perempuan menggunakan 53 format kata dengan 48 adalah compound words, 5 clipped form. Dari 5357 kata dalam genre ini penggunaan format kata oleh kelompok ini hanya $0.99 \%$ saja. Sementara itu, kelompok pembelajar laki-laki pemerolehan format kata dalam deskripsi teks adalah $0.69 \%$ yang kesemuanya adalah penggunaan compound word.

Analisis struktur teks naratif pada kelompok pembelajar perempuan menunjukkan persentase $82 \%$. Pada fase orientasi $87 \%$ partisipan dari kelompok ini berhasil memberikan gambaran kapan, dimana dan siapa pelaku yang akan diceritakan dalam cerita yang akan mereka tulis, namun pada fase komplikasi dan resolusi $13 \%$ partisipan kelompok ini gagal mengantarkan pembacanya untuk memahami masalah dan mendapatkan ending dari penyelesaian konflik yang mereka ceritakan.

Sementara itu, kelompok pembelajar laki-laki hasil analisis struktur teks naratifnya adalah $87 \% .13 \%$ persen yang lain merupakan teks naratif yang gagal karena 
struktur teks yang ditemukan adalah struktur teks recount karena tidak ditemukannya konflik dalam tulisannya.

Ditinjau dari aspek pemerolehan gramatikal, persentase correct grammar pembelajar perempuan dalam genre ini adalah $63.88 \%$. Persentase error grammarnya adalah $37.88 \%$. Sementara itu, correct grammar kelompok pembelajar laki-laki dalam genre naratif adalah $52.22 \%$ sedangkan error grammarnya adalah $47.78 \%$.

Misapplied adalah kategori error grammar yang paling dominan dalam genre ini. Misapplied merupakan kesalahan gramatika yang disebabkan pembelajar bahasa salah dalam menggunakan aspek gramatika yang sesuai dengan bentuk waktu yang dituntut di dalam klausa. Pada kelompok pembelajar perempuan, kategori error ini menunjukan bahwa kelompok pembelajar perempuan cenderung belum paham dalam mencocokkan penggunaan sembilan aspek dasar gramatikal dengan bentuk waktu yang dituntut dalam klausa atau kalimat yang ada. Aspek gramatikal yang kesalahanyan terbanyak dalam kategori misapplied ini adalah copula dan irregular verb. Dalam menggunakan copula dan irregular verb, partisipan perempuan cenderung tidak bisa membedakan kapan copula was/were, am/is/are dan be diaplikasikan dalam kalimat yang mereka buat sesuai tuntutan bentuk waktu. Begitu juga dalam menggunakan irregular verb, mereka belum tepat menggunakan perubahan bentuk pertama, kedua dan ketiga dari verba yang digunakan dalam kalimat-kalimat mereka.

Sedangkan pada pembelajar kelompok laki-laki misapplied yang tertinggi ditemukan pada aspek irregular verb dan regular verb. Dari hasil ini menunjukkan bahwa para pembelajar laki-laki tidak menguasai perubahan bentuk verba menurut bentuk waktu yang digunakan. Mayoritas mereka benar saat menggunakan bentuk pertama dari irregular dan regular verb tersebut tetapi salah saat menggunakannya 
dalam bentuk past tense (V2) atau participle (V3). Selanjutnya, misapplied juga terjadi pada penggunaan aspek copula, diikuti auxiliary, third person singular, possessive dan artikel. Untuk -ing dan plural tidak ditemukan masuk dalam kategori misapplied error ini.

Error pada kategori misapplied dan misformation yang ditemukan dalam penelitian ini menunjukkan bahwa para pembelajar bahasa Inggris di PS Sastra Inggris UNIVED ini kompetensinya masih rendah. Seperti yang dikemukakan oleh Chomsky (1965) bahwa linguistik dibagi menjadi dua kelompok besar yaitu Linguistik competence dan performance. Competence/kompetensi menunjuk pada pengetahuan dasar seseorang tentang sistem, kejadian atau fakta. Kompetensi merupakan kemampuan yang teramati dalam melakukan sesuatu dan dalam melakukan sesuatu. Dalam bahasa, kompetensi merupakan pengetahuan mendasar tentang system bahasa, kaidah-kaidah tata bahasanya, kosakatanya, seluruh pernak-pernik bahasa dan bagaimana menggunakannya.

Pada aspek analisis pemerolehan format kata, kelompok pembelajar perempuan hanya menggunakan format kata sebesar $0.60 \%$ dari 6164 kosakata yang meraka gunakan. Sedangkan pembelajar laki-laki indeks format kata yang digunakan adalah $1.87 \%$ dalam genre ini.

\section{SIMPULAN}

Partisipan dari kedua kelompok berhasil menuliskan struktur teks deskripsi dengan teratur, berurutan dan benar. Sementara pada genre teks naratif, dari tiga aspek struktur teks naratif (orientasi, komplikasi dan resolusi) kedua kelompok pembelajar ini 
juga berhasil menuliskannya dengan sempurna sesuai dengan struktur teks yang dimaksudkan.

Pada pemerolehan gramatikal yang diukur melalui sudut pandang Correct grammar dan Error grammar dari Sembilan aspek gramatikal (copula, auxiliary, third person singular, -ing, regular verb, irregular verb, article, plural dan possessive) menunjukan bahwa para pembelajar bahasa Inggris sebagai bahasa asing di PS Sastra Inggris UNIVED masih belum baik. Kategori error misformation dan misapplied yang paling dominan dilakukan oleh kedua kelompok pembelajar menggambarkan bahwa performan sebagian besar para pembelajar bahasa Inggris ini belum memahami kaidah bahasa Inggris yang baik dan benar. Tampak bahwa kompetensi gramatikal mereka masih sangat rendah sehingga dapat disimpulkan partisipan dalam penelitian ini pemerolehan aspek gramatikal bahasa Inggris sebagai bahasa asing mereka juga masih rendah. Sedangkan pada aspek pemerolehan format kata (Compound word, blending dan clipped form) secara keseluruhan indeks penggunaan format kata pada kelompok pembelajar masih berada pada level elementary learners. Akhirnya dilihat dari ketiga aspek penelitian di atas, dengan demikian dapat disimpukan bahwa pada di Program studi Sastra Inggris Universitas Dehasen Bengkulu pembelajar laki-laki lebih baik pemerolehan Bahasa Inggrisnya dibandingkan pembelajar perempuan.

\section{SARAN}

Pada penelitian ini belum dilakukan analisis keterampilan menulis semua genre teks. Diharapkan pada penelitian selanjutnya dapat menyempurnakannya dengan lebih banyak menganalisis genre teks. Selain itu, pada penelitian ini fokus utamanya adalah pemerolehan gramatika, sedangkan pemerolehan kosakata hanya dibatasi pada 
pemerolehan format kata saja. Diharapkan penelitian pemerolehan kosakata dapat lebih diperdalam sebab pemerolehan kosakata pembelajar bahasa di lihat dari banyak aspek yaitu: subcategorization, word association and networks, word formation, word combinations, collocation dan phraseology.

Saran kepada para pembelajar bahasa Inggris sebagai bahasa asing di prodi sastra Inggris UNIVED Bengkulu diharapkan dapat lebih meningkatkan pemerolehan gramatika, kosakata dan kemampuan menulis sehingga semua lulusan sastra Inggris UNIVED Bengkulu dapat bersaing dengan lulusan dari universitas-universitas lain. Kemudian kepada bapak/ibu dosen pada Prodi Sastra Inggris UNIVED Bengkulu dapat memvariasikan metode pengajaran bahasa Inggris sebagai bahasa asing yang paling tepat dan sesuai dengan karakteristik dan kompetensi para mahasiswa Program Studi Sastra Inggris UNIVED sehingga kualitas pemerolehan para pembelajar ini juga dapat meningkat kualitasnya.

\section{DAFTAR PUSTAKA}

Amrina, Lia Amalia. 2014. Analisis kesalahan gramatika pada karangan Bahasa Inggris siswa kelas bilingual SMP Muhammadiyah 3 Yogyakarta. Yogyakarta. Universitas Gajah Mada.

Biber, D. Johansson,S. Leech, G. Conrad, S. Finegan,E. 2007. Grammar of spoken and written english. London. Longman

Birdsong, D, Mollis. M. 2001."On the evidence for maturational constraints in second language acquisition. Texas. Journal of memory and language 44, 245-249.

Blaxter.L, Hughes.C \& Tight.M. 2006. How to research. Philadelphia. Open University Press

Brown, H. Douglas. 2007. Prinsip Pembelajaran dan Pengajaran Bahasa (terjemahan Noorholis dan Yusi Avianto). USA: Pearson Education.

Chaer, Abdul. 2009. Psikolinguistik : Kajian Teoritik. Jakarta : Asdi Mahasatya. 
De Bolt, K. Lowie, W \& Verspoor, M. 2007. A dynamic system theory approach to second language acquisition. USA. Cambridge University Press.

Djatmika. 2015. Memahami seluk beluk teks. Surakarta. Media Insani Publishing

Ellis, Rod. 1994. The Study of Second Language Acquisition. Oxford: Oxford University Press.

Friedman, Debra A.2012. How to collect and analyze qualitative data, hlm. 180-200. Dalam Mackey, Alison \& Gass, Susan M (edt). Research Methods in Second Language Acquisition: A Practical Guide. London. Blackwell Publishing Ltd

Gass, Susan M. Dan Larry Selinker. 2008. Second Language Acquisition: An Introductory course. New York and London: Routledge.

Hall, C.J, Smith, P.H \& Wicaksono, R. 2012. Mapping Applied Linguistics. A guide for students and practitioners. London \& New York. Routledge

Krashen, Stephen D. 1982. Principles and Practice in Second Language Acquisition. University of Southern California.

Kridalaksana, Harmurti. 1993. Kamus Linguistik. Jakarta. Gramedia

Larsen-Freeman, Diane. 2014. An introduction to second language acquisition research (Applied linguistics and language study). New York. Routledge

Lincoln. Y.S., \& Guba, E.G .1985. Naturalistic inquiry. Beverly Hills .Sage Publication

Mackey, A. Gass, Susan M. 2005. Second language research. Methodology and design. London. Lawrence Erlbaum Associates, Inc., Publishers.

Maicusi,T. Maicusi.P . 2000. The error in the second language acquisition. Granada. Universidad de Granada

Menezes, Vera. 2013. Second language acquisition : Reconciling theories. Brazil. Open Journal applied science, 3, $404-412$.

Murphy, R. 1990. English Grammar in Use. USA: Cambridge University Press.

Nurmayanti. 2007. Pemerolehan bahasa kedua pada anak (studi kasus di Britton International School). Yogyakarta. Universitas Gajah Mada

Parera, Jos Daniel. 1993. Linguistik edukasional: Metodologi Pembelajaran Bahasa, Analisis Kontrastif Antarbahasa, Analisis Kesalahan Berbahasa. Edisi Kedua. Jakarta: Erlangga.

Parera, Jos Daniel. 1994. Sintaksis. Jakarta. Gramedia Pustaka Utama 
Pica, Theresa. 2005. Second language acquisition research and applied linguistics". Pensyllvania. Penn Libraries University of Pensyllvania.

Santiago,. G. 2011. Acquisition of morphosyntax in the adult second language: the phonology factor. Iowa. Iowa research online theses and dissertations.

Santosa, Riyadi . 2009. Metode Penelitian Kualitatif Kebahasaan : Draf Buku. Surakarta

Spradely.J.P. 2006. Metode Etnografi. Yogjakarta. Tiara wacana

Stefensson,. E.G. 2013. "Second language acquisition : the effect of age and motivation". Islandia. Siggilum Universitas Islandia

Sutopo, H.B .2002. Metodologi Penelitian kualitatif. Sebelas Maret University Press. Surakarta

Thomson, A. J. dan A. V. Martinet. 1986. A Practical English Grammar. London.Oxford University Press

Veerappan, V. Md Yusuf, DS. Md Aris, A. 2013. Language-Switching in L2 Composition among ESL and EFL Undergraduate Writers. The linguistics journal juli 2013 vol 7 issue 1 .

Wang, Chengjun. 2009. On linguistics environtment for foreign language acquisition. China. Asian culture and history journal Vol. 1, no.1.

Zulaeni, Erna. 2007. Pemerolehan bahasa kedua siswa taman kanak-kanak di Yogyakarta International School: study kasus di Yogyakarta. Yogyakarta. Universitas Gajah Mada.

http://www.grammarinenglish.com

http://www.oxforddictionaries.com 